\title{
А.В. Луценко
}

\section{К. МАРКС И А. БОГДАНОВ О РЕВОЛЮЦИИ В РОССИИ}

\begin{abstract}
Проводится сопоставление взглядов К. Маркса и А.А. Богданова на возможность и перспективы осуществления революции в Российской империи, с одной стороны, и реального хода событий, завершившихся Февральской революцией 1917 г. и Гражданской войной, с другой стороны. Делается вывод о сугубо диагностическом, а не политико-пропагандистском характере теоретических выкладок Маркса и Богданова, констатируется совпадение выводов ученых с последующими историческими событиями, что характеризует эффективность как марксистской, так и богдановской методологии исследования.

Ключевые слова: марксизм; капиталистическая формация; революция; Российская империя; крестьянская община.
\end{abstract}

В истории человечества известно немало попыток заглянуть за грань времени, чтобы разобраться в прошедшем, предугадать в настоящем черты будущего и увереннее подготовиться к предстоящей жизни. Именно этому стремлению во многом обязана своим появлением на свет историческая наука - наука о причинах великих событий Прошлого, которую древние римляне называли «учительницей жизни». Но чем старше становилось человечество, тем яснее оно осознавало, что история сама по себе не позволяет избегнуть ошибок в будущем, поскольку анализ и реконструкция событий предшествующих эпох осуществлялись лишь по нескольким сторонам жизни общества, которые представлялись исследователю наиболее значимыми. Так, если для средневековых летописцев важнее всего были деяния государей, то для историков-гегельянцев XIX столетия эти же события были всего лишь одной из стадий саморазвития Мирового Духа, а для марксистов приоритетным объектом исследования становятся вопросы экономического развития общества, распределения в нем прав собственности на средства производства, а также проблема борьбы классов.

Таким образом, любая историческая теория по большому счету представляет собой упрощенную модель конкретного состояния действительности и остается адекватной лишь до тех пор, пока действительность остается неизменной. Наиболее отчетливый пример этого буквально перед глазами: современная западная цивилизация, еще совсем недавно признаваемая «ядром капиталистического мира», со второй половины XX столетия стала представлять собой одну из загадок истории.

При этом бросаются в глаза противоречивые изменения в характере мировой цивилизации, явно не вписывающиеся ни в одну, даже марксистскую, методологию анализа капиталистического общества, вследствие чего в современном научном мире возник своего рода «методологический вакуум», препятствующий рациональному осмыслению происходящих явлений и, соответственно, выработке стратегии не только научного исследования, но и прежде всего практической деятельности, лишь во взаимодействии с которой наука приобретает реальное значение. В России эти обстоятельства осложнились еще и яростным неприятием политизированной общественностью той идеологической составляющей советского периода, которая была основана на теории марксизма.

Все это вместе взятое к моменту вступления цивилизации в «однополярный мир» привело к тому, что наука, больше не имевшая, по сложившемуся мнению, оснований использовать методологию классического марксизма и переживавшая «методологический кризис», только и могла приблизительно обрисовать наиболее существенные для современного общества тенденции развития, но была бессильна дать четко определенный ответ, каким должен быть выход из тупика, когда эскалация всех видов социального противостояния прямо угрожала распадом существующей системы отношений. Носители политических доктрин, озабоченные состоянием общества, обычно игнорировали связь между осуществлением задуманных проектов и подготовленностью масс к переменам, что вело к непредвиденным последствиям. Мировоззренческая неадекватность была присуща и большинству российских политиков, даже вполне здравомыслящих и позитивно настроенных: к середине XX в. они несмело констатировали, что марксизм в его предельно догматической версии со ставкой на революционную борьбу как единственный способ разрешения всех социальных конфликтов отжил свой век, особенно в условиях изменения структуры общества, когда классы утратили ряд известных признаков, приобретя взамен новые. Оглядываясь на «процветающий Запад», оппозиция открыто повела активную агитацию за новую жизнь и стала требовать смены общественного строя.

Однако на деле страну «перестроили» в полном соответствии с постулатами отвергнутой «предельно идеологизированной» теории путем бескомпромиссного переворота. Пришедшие к власти новые вожди не уставали повторять, что революция, которую они совершили, была бескровной, а значит, всеми принимаемой без протеста, раз защищать свергаемый строй оказалось некому. С этими заявлениями можно было бы согласиться, если бы в них не таилось лукавство: 
в России все революции, включая Октябрьскую, были бескровными, кровавыми были только народные бунты. Если обратиться к истории, то российский народ всегда «безмолвствовал» при смене властной верхушки и ее политического курса, руководствуясь правилом «Поживем - увидим», а сообща бунтовать и заливать кровью «ненавистных сатрапов» поднимался, когда политика властвующих начинала радикально противоречить жизненным тенденциям подавляющего большинства населения, разрушая существующую систему общественных отношений. В этом случае бунт представлялся единственной формой коллективной самозащиты.

Кроме того, реформаторы, отказываясь от идеологии, предопределявшей усвоенные народом огромной страны стереотипы мышления и образа жизни, не учли, что, пока в мире существует капиталистическая система отношений, выбранная политиками в качестве приоритетной для развития «перестроенного» общества, будет существовать и потребность в объективном исследовании ее потенциальных возможностей. Пытливая мысль может найти немало подсказок в фундаментальном труде Маркса о формационных признаках капитализма, а также в исследовательских трудах других его последователей, которые продолжили аналитическую работу по изучению фаз развития капиталистической цивилизации. Отказаться от их научного опыта - непозволительная роскошь, поскольку трансформация отношений в современном мире совершается с большими потерями для людей, стран и всего человечества.

В связи с этим для эффективной реализации позитивных проектов требуется новая методология исследования общественно-политических процессов, которая сочетала бы четкость анализа, в высшей степени характерную для марксизма, с открытостью новым фактам и идеям. Только при таком исследовательском подходе вниманию и пониманию людей становится доступной объективная реальность, а не набор унаследованных от прошлого идеологических мифов, с помощью которых осуществляется манипуляция сознанием общества, но которые на самом деле не имеют к реальности никакого отношения.

Наиболее влиятельным в современной политике представляется миф о марксистских философскоидеологических истоках русской революции, искажавший до неузнаваемости научное суждение Маркса. В «Капитале», взятом за теоретическую основу программы российских социал-демократов, рассматривалась тема исторической перспективы западноевропейского капиталистического производства, которая со временем сведется к тому, что «оно само» создаст «элементы нового экономического строя <...>, что капиталистическая собственность, в основе которой уже фактически лежит коллективная форма производства, не может не превратиться в собственность общественную» [1. С. 120]. В основополагающем труде Маркса не говорится о принциипиальной неотвратимости революции в качестве обязательного способа устранения эксплуататорского строя. Даже в «Манифесте Коммунистической партии» авторы теории марксизма писали о «преодолении» (Aufhebung в немецком оригинале) частной собственности [2. С. 39], в то время как в переводе Г.В. Плеханова эта часть «Манифеста» передается словами с иным смыслом: «Коммунисты могут выразить свою теорию одним положением: уничтожение частной собственности» [3. С. 441]. В русском языке «преодолеть» («одолеть») означает «пересилить», «справиться», но не «уничтожить» («истребить») [4. С. 366, 473]. Сам переход прибавочного продукта из рук капиталиста в общественную собственность виделся теоретику как процесс исторически пролонгированный, если только усиленно развивающаяся «капиталистическая горячка» не подтолкнёт революционное движение пролетариата Европы к насильственному переделу собственности. Здесь недопустима подмена понятий: самопроизвольный процесс и процесс спровоцированный, обусловленный внешним воздействием, - это далеко не одно и то же.

Что касается революционного свержения монархического строя в России, то Маркс на этот счет имел особое мнение, которое сложилось благодаря «специальным изысканиям». Здесь полезно отметить, что ни один из политических лидеров ни в XIX, ни в XX в. не взялся за тот титанический труд, который добровольно взвалил на свои плечи немецкий исследователь Карл Маркс, прежде чем вынести собственный вердикт относительно будущего огромной крестьянской империи на востоке Европы. Предварительно выучив русский язык, он на протяжении последних восьми лет жизни целенаправленно исследовал экономические и исторические условия России по первоисточникам. Казалось бы, для получения представлений достаточно было ознакомиться с сообщениями о состоянии финансов и сельского хозяйства страны, составленными Н.Ф. Данилевским, русским экономистом, тем более, что эти сообщения базировались на сопоставлении официальной статистики и земских сведений. Но Маркс хотел иметь объемное представление о хозяйственной структуре страны, поэтому параллельно проанализировал выводы IV выпуска «Военно-статистического сборника», изданного русским Генеральным штабом, проштудировал 10 томов «Трудов податной комиссии» и «Свод отзывов губернских присутствий по крестьянским делам». Он с большим вниманием отнесся к монографиям и научным исследованиям видных русских экономистов XIX в. В процессе разработки указанной тематики Маркс обращался также к «Истории государства Российского» Н.М. Карамзина, «Историческим монографиям и исследованиям» Н.И. Костомарова, произведениям Н.Г. Чернышевского, М.Е. СалтыковаЩед-рина. Подробно, делая пометки и выписки, Маркс исследовал труды ученых - В.И. Семевского «Крестьяне в царствование императрицы Екатерины II», А.А. Исаева «Артели в России», В.П. Воронцова 
«Судьба капитализма в России», А.И. Скребицкого «Крестьянское дело и царствование Александра II», А.А. Головачева «Десять лет реформы 1861-1871», Ю.Э. Янсона «Опыт статистического исследования о крестьянских наделах и платежах», Ф.П. ЕленеваСкалдина «В захолустье и столице», А. Гакстгаузена «Сельское устройство России», И.И. Патлаевского «Денежный рынок в России от 1700 до 1762», Н.А. Каблукова «Очерк хозяйства частных землевладельцев», М.М. Ковалевского «Общинное землевладение, причины, ход и последствия его разложения» [5].

Словом, Маркс всесторонне изучил проблемную тему России. Литературы о ее социально-экономическом положении у Маркса было много: он эти книги выделил особо, назвав «Russishes in my bookshelf» («Русское на моей книжной полке») [Там же]. Не удовлетворившись изучением книг с это полки, он уточнял полученную информацию во время личных встреч с П.Л. Лавровым, Н.Ф. Даниэльсоном, М.М. Ковалевским, Н.И. Утиным, Л. Гартманом, Н.А. Морозовым, К. Гиршем и другими, вел активную переписку со многими из них, в том числе с В.В. Берви-Флеровским, который отбывал ссылку в сибирском Томске и книгу которого «Положение рабочего класса в России» немецкий ученый высоко оценил, сопоставив ее с исследованием Энгельса об участи английского пролетариата [6]. Осмысление двухтомного труда А.И. Васильчикова «Землевладение и земледелие в России и других европейских государствах», равно как и всех перечисленных выше работ, шло через сопоставление с данными западноевропейских ученых. Анализ исследований Г.П. Маурера, Г. Хансена, Ф. Демелича, О. Утешновича, Ст. Янчини, Дж. Мани, Дж. Фира, У. Карлтона, Г. Мейна, Ф. Карденаса, Л. Кремаза, посвященных изучению земледельческой общины в странах Европы и в Индии, потребовал расширения знаний по всемирной истории, и Маркс для получения информации о роли крестьянской общины в истории народов всего европейского континента, о причинах и условиях уничтожения ее в ходе разложения феодализма воспользовался фактическим материалом, какой нашел в 18-томной «Всемирной истории» Шлоссера, в «Истории России» Келли, в «Истории России и Петра Великого» Сегюра, в работах Ботта, Коббета и других известных западноевропейских историков [5]. Результатом изучения и сравнительного анализа событий общеевропейского масштаба за период с I в. до н.э. по XVII в. н.э. было появление четырех тетрадей «Хронологических выписок» Маркса объемом около 105 печатных листов (т.е. около 1900 книжных страниц) [Там же], и только смерть помешала ученому превратить эти заметки в целостное исследование, - возможно, сопоставимое по масштабу с «Капиталом».

Вывод Маркса на основе изученных материалов оказался полной неожиданностью для русской интеллигентной оппозиции, сражавшейся против монархического строя и связанной с ним «дряхлой» крестьян- ской общины: автор «Капитала» был убежден, что «западный прецедент» не имеет смысла для сообществ $c$ другими типами цивилизационного развития. Что касается российской общины, то она, по мнению К. Маркса, являлась «точкой опоры социального возрождения России» [7. С. 412; 8. С. 251], и в набросках ответа на письмо В.И. Засулич он объяснял почему. При этом немецкий исследователь настойчиво предостерегал русских «поклонников капиталистического строя», что грабительская фискальная политика самодержавия гарантированно приведет земледельческую Россию к невиданной по масштабу социальной катастрофе - коренному слому привычного уклада жизни подавляющего большинства населения. Дело в том, что об отмене крепостного права в империи царь«освободитель» Александр II торжественно объявил всему миру в 1861 г., оставив, правда, крестьянское население на положении юридических «полуперсон», лишенных средств к существованию, поскольку земледельцы были превращены в особое временнообязанное сословие вплоть до 1932 г. - и выкуп за это назначили неподъемный. По официальным данным, опубликованным в XXII томе «Трудов податной комиссии» (1873), бывшие крепостные отдавали в казну государства в общей сложности $198,25 \%$ от уровня своего сельскохозяйственного дохода [9. С. 434]. Необходимо особо отметить: от такой «грабиловки» и других напастей, добавленных позднее, русская деревня вот уже полтора столетия медленно умирает и, впав в состояние стойкой фрустрации почти сразу после 1861 г., по сей день не может прийти в норму, спиваясь, глупея, теряя трудовые навыки и веками наработанные национальные традиции.

Маркс считал, что в той гуманитарной катастрофе, какая после крестьянской реформы 1861 г. постигла $85 \%$ российского населения (а в империи было ровно столько земледельцев), повинно не только самодержавное правительство. Вину за случившееся с крестьянством в России, по мысли ученого, должно было взять на себя образованное «русское общество, так долго жившее на счет сельской общины» [7. С. 414]. Земледельческое население по собственному разумению воспринимало его как ярмо на шее. В сознании крестьян интеллектуальная элита, ставшая кастой «господ», отождествлялась с правительственными сатрапами и чиновниками-бюрократами, несмотря на сочувственное отношение к крестьянам во времена «хождения в народ», прозывалась внутри общины «захребетниками», - шумными, кичливыми, праздными, всем недовольными, все осуждавшими, но ни на что реально не способными. И хотя часть интеллигенции, относившая себя к числу противников монархии, в 1861 г. победно ликовала, считая «отмену рабства» в России собственной заслугой, в действительности она мало что из случившегося поняла.

Отпраздновав триумф, оппозиция была разочарована плачевными итогами реформы и обвинила в бед- 
ственном положении крестьянства... самих крестьян, поскольку для интеллигенции всегда важно было ответить на вопрос «Кто виноват?» На страницах российской печати и либерального, и демократического направления очень скоро стала утверждаться идея, что в стране на самом деле не «обескровливают и терзают общину», а просто адекватно оценивают ее «раны, как симптомы ее естественной и неоспоримой дряхлости, и уверяют, что она умирает естественной смертью, и что сократить ее агонию было бы добрым делом. Речь идет здесь, таким образом, уже не о проблеме, которую нужно разрешить, а просто-напросто о враге, которого нужно сокрушить $<\ldots>$, нужна русская революция $<\ldots>$, русское правительство и “новые столпы общества" делают все возможное, чтобы подготовить массы к такой катастрофе», - констатировал в 1884 г. состояние русской общественной мысли Карл Маркс в набросках ответа на письмо В.И. Засулич и сравнивал стремление ликвидировать общину с намерением «убить курицу, несущую золотые яйца» [7. С. 410], поскольку из изученных источников знал, что именно на деятельности общины базируется вся хозяйственная система Российской империи.

Таким образом, то, с чем обрашался К. Маркс к русской оппозиции, никак нельзя было назвать призывом к революции, потому что немецкий исследователь считал: России необходима революция особого рода - та, что совершит переворот в умах касты «господ»! Суть этого переворота, по его мнению, состояла в уяснении того, что «русское общество < ..> обязано авансировать ей (сельской общине, существующей “в национальном масштабе”. - А.Л.) первоначальные средства для <...> того, чтобы поставить общину в нормальное положение на ее нынешней основе» [Там же. С. 412]. Маркс эту свою позицию неоднократно излагал русским противникам монархического режима - и народникам, и либералам, и социал-демократам, и анархистам. Однако все они, по свидетельству самого автора «Капитала», «придерживаются <..> совершенно противоположных взглядов» [Там же]. Позже это несогласие с Марксом проявилось в том, что российские лидеры разных идеологических пристрастий, будто вступив в негласный сговор, утаили от политизированной широкой общественности, что на самом деле родоначальник марксизма ни теоретически, ни практически не имел отношения к револючии в России. Он не только не призывал к перевороту, но напротив - активно предостерегал от этой непоправимой беды: по его мнению, ни революция европейского образца, ни западный путь развития не нужны России, потому что дело неминуемо обернется насильственным подчинением многомиллионного населения неумолимым законам капитализма с трагическим финалом - необратимой деградацией всей нации $[1,7]$.

Богданов наверняка не знал об этой точке зрения К. Маркса, но после Декабрьского восстания 1905 г. он тоже пришел к убеждению о стратегической несостоя- тельности идеи революционного переворота. Отголоском этого вывода служит эпизод из «Красной звезды» (1908), где обсуждался вопрос, принесет ли реальную пользу крайний радикализм, если пожертвовать «полуварварской» системой общественных отношений, вместо которой, как предполагалось, «развернется <...> жизнь несравненно более гармоничная в ее непрерывном, беспредельном развитии» [10. С. 186]. Симпатии Богданова, судя по всему, оказались на стороне тех, кто считал, что «уничтожить, навеки истребить целый своеобразный тип <..> жизни, тип, которого потом мы никогда уже не сможем ни восстановить, ни заменить» [Там же], - это безответственный способ «подправить» историю вопреки естественному ходу ее развития. Коренной перелом жизни с целью устранения назревших общественных противоречий путем насильственной смены власти не поможет позитивно осуществить задуманные планы, а значит, не решит поставленную задачу, став поистине катастрофой для населения, не подготовленного к переменам, ибо «в столкновении двух миров < .. > нет компромиссов» [Там же].

Средством к достижению позитивной преобразовательной цели являлась, по мнению Богданова, не разрушительная социальная катастрофа, а объединение разрозненных сил, не принесение в жертву одних ради победы других, а осознанное приближение эпохи, «когда впервые может осуществиться соединение двух великих линий жизни» [Там же]. Богданов был уверен, что из этого сочетания обязательно возникнет новое многообразие, та «высшая гармония», какая получается, когда люди заимствуют друг у друга все лучшие качества и вместе строят новую жизнь. Ученый без устали доказывал соратникам, что, даже если «мировая жизнь едина» [Там же], и для России назрела пора идти в ногу с развитыми странами, то это вовсе не означает, будто ради этого надо стереть с лица земли всех не похожих на избранный идеал - вместе с их историей, традициями и психологией, - только потому, что «они иные» [Там же. С. 187]. «Устраняя их, - писал А.А. Богданов в 1908 г., - мы их не заместим в мировом развитии, мы только механически заполним собою ту пустоту, которую создадим в царстве форм жизни» [Там же].

Однако то, что произошло в России в конце февраля 1917 г., явилось для многих неожиданностью, называемой в мемуарной литературе «бескровной революцией» - скорее всего потому, что при передаче власти не пролилась монаршья кровь, хотя трупов на мостовых Петрограда было немало. По мнению военного историка-эмигранта, автора 4-томной «Истории русской армии» А.А. Керсновского, для российских «общественников», борцов с монархическим строем «эти трупы были поистине подарком небес, трамплином для прыжка к заветной цели - власти во что бы то ни стало $<. .>$. Важно было доконать заколебавшийся ненавистный режим, дорваться до власти и захватить все места для себя! Для этого надо было бунт превратить в рево- 
люцию» [11. С. 258]. А бунт начался с большой крови: 27 февраля разгромили арсенал, расправлялись всюду с полицейскими, открыли двери из тюрем, сожгли окружной суд; 28 февраля в столице начались бои с защитниками монархии; 1 марта бунт из Петрограда перекинулся в Кронштадт, и его тоже залили кровью, подвергнув дикой расправе офицеров эскадры, в числе которых погиб адмирал Непенин и технические специалисты, обслуживавшие корабли Балтийского флота [Там же. С. 259-261]. Когда флотские экипажи еще продолжали резню, в Петрограде «общественники» предвкушали свое победное вхождение во власть: «надо было ковать железо, пока оно было горячо, использовать до конца внезапно предоставившуюся блестящую возможность $<\ldots>$. Милюков говорил: "Комбинация из Алексея Николаевича и Михаила выгодна: один - больной ребенок, другой - совсем глупый человек”» [Там же. С. 261]. 9 марта 1917 г. царская семья была арестована.

Восемь месяцев Временное правительство усердно ломало то, что имело отношение к нормам жизни при царе. При этом все, на что была способна новая власть, которая объявляла себя либерально-демократической, подчинялось либо ненависти к самодержавию, либо страху прослыть «старорежимной»: и «...не было удара, которого эти люди не согласились бы нанести своей стране во имя этой ненависти и этого страха» [Там же. С. 267].

Действия Временного правительства, по признанию многих эмигрантов, покинувших Россию после октября 1917 г., свидетельствовали о том, что Октябрьской революции можно было избежать, будь во главе государства люди ответственного слова, а не хлесткой лозунговой фразы, люди дела, а не позы, люди анализа, а не авантюрных экспериментов. Но Великой России не повезло с властвующими: «...страной взялись управлять люди, до той поры не имевшие никакого понятия об устройстве государственного механизма. Пассажиры взялись управлять паровозом по самоучителю и начали с того, что уничтожили все тормоза. 5 марта Временное правительство одним росчерком пера упразднило всю русскую администрацию. Были отрешены все губернаторы и вице-губернаторы. Возвращены все политические ссыльные и уголовные каторжники, упразднены полиция и корпус жандармов. Призваны в Россию все эмигранты-пораженцы, агенты неприятеля, и упразднена контрразведка. Объявлена свобода, и брошены в тюрьмы тысячи инакомыслящих "реакционеров". Провозглашена "война до победного конца" и уничтожена дисциплина в армии» [Там же]. Последовавшие за этим Октябрьская революция и Гражданская война, а также массовые политические репрессии явились жесточайшим испытанием для всей нации.

Безусловно, трудно выстоять перед разрушительной силой подобной катастрофы. Но как бы ни пытались современники интерпретировать события вековой давности, нельзя забывать о рекомендациях двух ученых, к которым можно было прислушаться и во второй по- ловине XIX в., и в начале XX столетия, чтобы найти оптимальный вариант решения сложнейших проблем, не ввергая собственный народ в пучину бедствий, не загоняя его в опасный тупик, откуда выхода могло и не быть. И Маркс, и Богданов не для теории, а для практического знания выполнили комплексную социальноэкономическую и организационную диагностику состояния основной массы населения Российской империи. Проведенные исследования недвусмысленно показали, что страна ни в общественно-политическом, ни в культурно-мировоззренческом аспекте не была готова к радикальному переустройству. Более того, волюнтаристски насильственное вмешательство в жизненный уклад народа могло привести только к катастрофическим последствиям. События, начиная с первой четверти XX в., лишь подтвердили справедливость выводов двух выдающихся мыслителей.

На какие события в тот период следовало обратить особое внимание образованной интеллигенции, чтобы коллегиально выработать тактику и стратегию оздоровления больной экономики и перенапряженной социальной системы? Прежде всего, это касалось грабительской фискальной политики самодержавия, отмеченной Марксом. Эта проблема порождала необратимый процесс экономического упадка, хорошо заметный уже при взгляде на финансовую сторону дела: к 1909 г. государственный долг Российской империи составил 11800 млн руб., и покрыть его не удавалось ни за счет винной монополии, ни за счет увеличения косвенных налогов. «Недоверие за границей к русским финансам дошло до того, что в биржевых кругах и в печати Франции поставлен на обсуждение вопрос о взятии русских финансов под международный англофранцузский контроль: лишь под этим условием там считают возможным дать правительству новый громадный заем для общего исправления русских финансов, т.е. собственно для спасения прежних займов и процентов по ним от угрожающего рано или поздно банкротства» [12. С. 50]. Экономическая дезорганизация царской России закономерно завершилась вовлечением страны в войну за интересы кредиторов и введением в 1915 г. продовольственной разверстки; проводимые параллельно с этим массовые мобилизации крестьян в армию, реквизиции тяглового скота и продовольствия для военных нужд окончательно дестабилизировали общественно-политическую систему и вызвали кризис власти в феврале 1917 г. Оценивая постфактум эти события, очевидцы отмечали, что вина за революционные события «ложится, во-первых, на императорское правительство, не сумевшее ни предвидеть катастрофы, ни предотвратить ее, и это когда за долгие месяцы до февраля не то что люди, а сами камни петроградских мостовых кричали о готовившейся революции. Безмерна вина оппозиционной общественности, увидевшей в этом потрясении неповторимый случай прийти, наконец, к власти, захотевшей обратить несчастье Родины в средство для достижения своих узко 
эгоистических целей, в средство для насыщения своего чудовищного честолюбия. Обманутые общественностью военачальники сыграли роль позорную и жалкую $<\ldots>$. Их непростительной ошибкой было то, что они слишком стали считать себя “общественными деятелями” и недостаточно помнили, что они - прежде всего присягнувшие царю офицеры. <...> Эти три категории виновных - растерявшиеся сановники, предателиполитиканы и недостойные военачальники - не имеют оправдания. История вынесла им приговор, справедливый и беспощадный» [11. С. 326]. Этот вывод истори- ка-белоэмигранта Антона Керсновского обобщал большой массив данных из мемуарных источников, оставленных непосредственными участниками февральских событий, а также сотрудников Временного правительства, чьи воспоминания впоследствии были опубликованы в эмигрантских исследовательских изданиях, наподобие «Архива русской революции». Тем показательнее, что все эти данные совпали с диагностическими выкладками Карла Маркса и тектологическими анализами Александра Богданова, выполненными задолго до событий 1917 г.

\section{ЛИТЕРАТУРА}

1. Маркс К. Письмо в редакцию «Отечественных Записок» // Сочинения К. Маркса и Ф. Энгельса. 2-е изд. М. : Госполитиздат, 1961. Т. 19. C. $116-121$.

2. Кагарлицкий Б.Ю. Марксизм: не рекомендовано для обучения. М. : Алгоритм, Эксмо, 2005. 480 с.

3. Маркс К., Энгельс Ф. Манифест Коммунистической партии // Сочинения К. Маркса и Ф. Энгельса. 2-е изд. М. : Госполитиздат, 1956. Т. 4. С. $419-459$.

4. Ожегов С.И. Словарь русского языка. 27-е изд. М. : Мир и Образование, 2013.

5. Даты жизни и деятельности К. Маркса и Ф. Энгельса (март 1875 - май 1883) // Сочинения К. Маркса и Ф. Энгельса. 2-е изд. М.: Госполитиздат, 1961. Т. 19. С. 597-626.

6. Бурмакин Э. Последний утопист // Сибирские Афины. Томск, 1990. № 1 (апрель). С. 8-9.

7. Маркс К. Наброски ответа на письмо В.И. Засулич // Сочинения К.Маркса и Ф.Энгельса. 2-е изд. М. : Госполитиздат, 1961. Т. 19. С. 400-421.

8. Маркс К. Письмо В.И. Засулич // Сочинения К. Маркса и Ф. Энгельса. 2-е изд. М.: Госполитиздат, 1961. Т. 19. С. 250-251.

9. Маркс К. Заметки о реформе 1861 г. и пореформенном развитии России // Сочинения К. Маркса и Ф. Энгельса. 2-е изд. М. : Госполитиздат, 1961. T. 19. C. $422-441$.

10. Богданов А.А. Красная звезда // Богданов А.А. Вопросы социализма: Работы разных лет. М. : Политиздат, 1990. С. $104-203$.

11. Керсновский А.А. История русской армии : в 4 т. М. : Голос, 1994. Т. 4. 368 с., ил.

12. Платформа группы «Вперед» [декабрь 1909 г.] // Неизвестный Богданов : в 3 кн. М. : ИЦ «АИРО-ХХ», 1995. Кн. 2. С. $36-76$.

Lutsenko Anton V. Seversk Technology Institute of National Research Nuclear University «MIFI». E-mail: antom9@rambler.ru K. MARX AND A.A. BOGDANOV ABOUT REVOLUTION IN RUSSIA

\section{Keywords: Marxism; capitalist formation; revolution; Russian Empire; peasants' community.}

The direct purpose of this research is the analysis of K. Marx's and A.A. Bogdanov's views about principal opportunity and prospects of revolution in Russian Empire and the comparison of these scientists' theoretical conclusions with real course of the historical events which were finished with the February revolution of 1917 and the Civil war 1918-1921. Relevance of such purpose statement is defined by "methodological crisis" which characterizes a number of the influential directions of a modern scientific, social and political thought: supporters of these directions quite often base their researches not on real historic facts, but on ideological myths - first of all, on myth about Marxism as theoretical base of an aggressive and violent reorganization of social system. This article is analyzing works of K. Marx and A.A. Bogdanov (one of the most authoritative Russian Marxists at the beginning of 20th century). The analysis shows that theoretical positions of "Capital" were not political propaganda character, but especially diagnostic one, and they concerned exclusively Western European capitalist society. Marx in "Capital" spoke only about private property overcoming, assuming evolution of the western society from capitalism to socialism; the idea of private property destruction by revolution arose among the Russian Marxists because of the incorrect translation of Marx's words by G.V. Plekhanov.

Marx had special opinion about Russia. His opinion based on detailed studying of the Russian social, economic and political reality according to primary sources. From them the author of "Capital" made a conclusion that Russia is essentially other civilization type, which can not evolve to industrial society on the western patterns. Marx explained that westernization paradigm of social and economic development is unfit for Russia because the attempt to build capitalism due to peasantry expropriation can cause in Russian conditions only social explosion and political system destruction: radical pauperization of $90 \%$ of people is principally capable to cause only degradation of all nation. It was a reason why Marx rigidly criticized ideas of the Russian revolutionaries who thought that a peasants' community is one of the major obstacles to progressive transformations of Russia. Marx most negatively characterized actions of Russian Empire government which was interested in western-styled economic reform supported by taking $198.25 \%$ of peasants' agricultural work income from 1861 to 1932. As an alternative of western experience non-critical copying Marx offered for Russia a strategy of peasants' community integration into industrial productivity relations' system without any destruction of peasants' social and economic cooperation traditional form. A.A. Bogdanov did not know with these Marx's conclusions but he came to almost similar ideas on the basis of his own analysis of the Russian reality of the beginning of the 20th century: Bogdanov thought that the maximum integration of the peasantry not only in social and political, but also in economic and cultural life of the country is strongly needed because it could provide increase in structural stability of the Russian society. Historical events of 1909-1917 showed that the actual isolation of $90 \%$ of people from participation in social and political life in combination with unbalanced economic policy and noncritical copying of foreign economic organization experience open a way to the total disaster destroying the state and society.

\section{REFERENCES}

1. Marx, K. (1961) Sochineniya K.Marksa i F.Engel'sa [Works by K. Marx and F. Engels]. 2nd ed. Vol. 19. Moscow: Gospolitizdat. pp. 116-121.

2. Kagarlitskiy, B.Yu. (2005) Marksizm: ne rekomendovano dlya obucheniya [Marxism: not recommended for studying]. Moscow: Algoritm, Eksmo.

3. Marx, K. \& Engels, F. (1956a) Sochineniya K.Marksa i F.Engel'sa [Works by K. Marx and F. Engels]. 2nd ed. Vol. 4. Moscow: Gospolitizdat. pp. 419-459. 
4. Ozhegov, S.I. (2013) Slovar' russkogo yazyka [Dictionary of the Russian language]. 27th ed. Moscow: Mir i Obrazovanie.

5. Marx, K. \& Engels, F. (1956b) Sochineniya K.Marksa i F.Engel'sa [Works by K. Marx and F. Engels]. 2nd ed. Vol. 19. Moscow: Gospolitizdat. pp. $597-626$.

6. Burmakin, E. (1990) Posledniy utopist [The last utopian]. Sibirskie Afiny. 1. pp. 8-9.

7. Marx, K. \& Engels, F. (1956c) Sochineniya K.Marksa i F.Engel'sa [Works by K. Marx and F. Engels]. 2nd ed. Vol. 19. Moscow: Gospolitizdat. pp. $400-421$

8. Marx, K. \& Engels, F. (1956d) Sochineniya K.Marksa i F.Engel'sa [Works by K. Marx and F. Engels]. 2nd ed. Vol. 19. Moscow: Gospolitizdat. pp. $250-251$

9. Marx, K. \& Engels, F. (1956e) Sochineniya K.Marksa i F.Engel'sa [Works by K. Marx and F. Engels]. 2nd ed. Vol. 19. Moscow: Gospolitizdat. pp. 422-441.

10. Bogdanov, A.A. (1990) Voprosy sotsializma: Raboty raznykh let [Questions on Socialism: Works of Different Years]. Moscow: Politizdat. pp. 104203.

11. Kersnovskiy, A.A. (1994) Istoriya russkoy armii. V 4-kh t. [History of the Russian army. In 4 vols]. Vol. 4. Moscow: Golos.

12. Bordyugov, G.A. (ed.) (1995) Neizvestnyy Bogdanov. V 3-kh knigakh [Unknown Bogdanov. In 3 books]. Book 2. Moscow: AIRO-XX. pp. 36-76. 